\title{
Information Literacy in the Seminary
}

\author{
Patsy Yang, Gateway Seminary \\ Jonathan McCormick, Gateway Seminary
}

\begin{abstract}
The purpose of this conversation group was to develop a list of resources, ideas, and concerns related to information literacy in seminaries. The session started with some quick polls on how schools are doing information literacy (IL) right now. We learned that with COVID-19, almost everyone's teaching interfaces changed to online and most reference and IL interactions have been via Zoom, online classrooms, chat and email. After the polls, we formed four groups to discuss the following topics: Starting an IL Program, Administrative Buy-In to the Need for IL Training of Students, Tiered Approaches to IL, and Ways to Involve Faculty in IL. Each group provided their conversation results in a Google Doc. At the end of the session, we had a few minutes to hear back from some of the groups. Before and following the session, attendees continued to add to the ideas under each area and developed a non-comprehensive bibliography.
\end{abstract}

Below are the bibliography and notes from each of the small groups. One takeaway from our time together is that we need to continue this conversation. Some suggestions were to develop a LibGuide and have a followup webinar conversation group. An Information Literacy for Religion and Theology Google group (groups.google.com/ forum/\#!forum/information-literacy-religion-and-theology) was created after the session, which you are welcome to join. Members of that group may continue to add to the Google docs we started during the session.

\section{BIBLIOGRAPHY}

Association of Christian Librarians. n.d. "Information Liter-

acy Interest Group.” LibGuide. acl.libguides.com/c. php?g=350505\&p=6874777. [Includes bibliographies, syllabi, 
ACRL IL standards and frameworks and much more. Continuously updated.]

Badke, William B. 2012. Teaching Research Processes: The Faculty Role in the Development of Skilled Student Researchers. Witney, UK: Chandos Publishing.

Bash, Cassaundra. 2015. "One-on-One versus One-Shot: A Comparison of a General Psychology Class — Fall 2013 and Spring 2014." Catholic Library World 85, no. 3 (March): 167-71.

Bradley, James E. and Richard A. Muller. 2016. Church History: An Introduction to Research Methods and Resources. Second edition. Grand Rapids, Michigan: William B. Eerdmans Publishing Company.

Burkhardt, Joanna M. 2016. Teaching Information Literacy Reframed: 50 Framework-Based Exercises for Creating Information-Literate Learners. Chicago: Neal-Schuman.

Eyre, Jodi Reeves, John C. Maclachlan, and Christa Williford, eds. 2017. A Splendid Torch: Learning and Teaching in Today's Academic Libraries. Council on Library and Information Resources, ERIC Clearinghouse. eric.ed.gov/?id=ED577048.

Farmer, Lesley S. J. 2016. "Teaching Ethics to Teens via School Library Reference Services.” Catholic Library World 86, no. 4 (June): 242-50.

Farrell, R. and W. Badke. 2015. "Situating Information Literacy in the Disciplines: A Practical and Systematic Approach for Academic Librarians." Reference Services Review 43, no. 2: 319-40.

Gibson, Craig and Sharon Mader, eds. 2019. Building Teaching and Learning Communities: Creating Shared Meaning and Purpose. Chicago: Association of College and Research Libraries.

Harmeyer, D. and J. J. Baskin. 2018. Implementing the Information Literacy Framework: A Practical Guide for Librarians. Lanham: Rowman and Littlefield.

Hollister, Christopher Vance. 2010. Best Practices for Credit-Bearing Information Literacy Courses. Chicago: Association of College and Research Libraries. 
Jacobson, Trudi E. and Thomas P. Mackey. 2007. Information Literacy Collaborations that Work. Information Literacy Sourcebooks, vol. 4. New York: Neal-Schuman.

Kahneman, Daniel. 2012. Thinking, Fast and Slow. London: Penguin Press. [The insights this book offers are real gamechangers in getting students to look critically at their study/learning/ research habits.]

Kaplowitz, Joan R. 2014. Designing Information Literacy Instruction: The Teaching Tripod Approach. Rowman \& Littlefield.

Kidd, Terry T. and Jared Keengwe, eds. 2010. Adult Learning in the Digital Age: Perspectives on Online Technologies and Outcomes. Hershey, PA: Information Science Reference.

Lowe, M. Sara, Abby Currier, and Steven Graunke. 2020. "Documenting the Value of Librarians in the Classroom: Results from a Mixed-Methods Research Collaboration with Campus Partners.” College \& Research Libraries 81, no. 3 (April): 492-508. doi. org/10.5860/crl.81.3.492.

McClure, Randall and James P. Purdy, eds. 2016. The Future Scholar: Researching and Teaching the Frameworks for Writing and Information Literacy. Medford, NJ: Information Today, Inc.

McClure, Randall and M. Kramer. 2016. Rewired: Research-Writing Partnerships in a Frameworks State of Mind. Chicago, Illinois: Association of College and Research Libraries.

Neely, Teresa Y. 2006. Information Literacy Assessment: StandardsBased Tools and Assignments. Chicago: American Library Association.

Presnell, Jenny L. 2019. The Information-Literate Historian: A Guide to Research for History Students. Third edition. New York: Oxford University Press.

Ragains, Patrick and M. Sandra Wood, eds. 2016. The New Information Literacy Instruction: Best Practices. Best Practices. Lanham: Rowman \& Littlefield.

Reeves, Jodi, ed. 2017. A Splendid Torch: Learning and Teaching in Today's Academic Libraries. Washington DC: Council on Library and Information Resources. 
Stefaniak, Jill E., ed. 2020. Cases on Learning Design and Human Performance Technology. Advances in Human Resources Management and Organizational Development Book Series. Hershey, PA: Information Science Reference, IGI Global. doi. org/10.4018/978-1-7998-0054-5.

Smiley, Bobby, ed. Information Literacy and Theological Librarianship: Theory and Praxis. Chicago: Atla, 2019.

Solomon, Amy, Gwenn Wilson, and Terry Taylor, eds. 2012. 100\% Information Literacy Success. Second edition. Boston: Wadsworth, Cengage Learning.

Ullah, Midrar and Kanwal Ameen. 2019. “Teaching Information Literacy Skills to Medical Students: Perceptions of Health Sciences Librarians.” Health Information and Libraries Journal 36, no. 4 (December): 357-66. doi.org/10.1111/hir.12279.

Varnum, Kenneth J., ed. 2019. Beyond Reality: Augmented, Virtual, and Mixed Reality in the Library. Chicago: ALA Editions.

Wray, Christina C. and Renee C. Montgomery. 2019. Bridging the Skill Gap: Helping Non-Traditional Students Develop Research Skills When They Need It Most. Minneola, FL: Adult Higher Education Alliance. eric.ed.gov/contentdelivery/servlet/ ERICServlet?accno=ED577048.

\section{SMALL GROUPS}

Starting an IL Program

docs.google.com/document/d/1DlvZlPrCyjcLBQ3mSaRfYCF4BtlO2f H7VYva_wi37TA/edit

Unfortunately, no one was in this group or they were not able to take notes. We hope to address this area soon.

Administrative Buy-In to the Need for IL Training of Students docs.google.com/document/d/e/2PACX-1vStRO2TBKL3v1WbvHOHSvqs2LbGHM-v66GzPTdphr-uqntgVGpsgAYblFv4_lcBpOJBtF8wOeC_ x3hw/pub

- Use the ATS standards for IL to help administration see the need. 
- Approach the need for IL as a student formation issue (forming students in understanding news media in addition to the more traditional/academic side of IL through research).

- Ask faculty who do IL in their classes (or ask library staff who do it) to inform administration of improvements they see in research methods and writing style and why they started including IL in the first place.

- Ask Bill Badke and his academic dean(?) to do a webinar for ATS on IL and why they require this for all students.

Tiered Approaches to IL: What Different Schools Are Doing docs.google.com/document/d/1J83N44cqLODcEsbzqnXjMby4meXMspSOhxnGfDYcOM/edit?usp=sharing

- New student orientation. 1-2 hour seminar. -B. Mayer

- New student orientation. Faculty are excited about Zotero. Oneon-one engagement with students. -Tonya Fawcett

- Mandatory info session for MDiv. 3-hour session covering the library catalog, accessing e-books and more. -Daniel Baek.

- Required session. Website with YouTube videos for instruction and commentary access. -Katie Kinney Writing Center at Covenant

- Online orientation. Run through student services. DMin session for first semester students. No organized faculty connection. Biblical studies faculty refer students to the library. -Kenneth Cochrane

- A lot of faculty conferences with HathiTrust access. -Megan Welsh (public university with bachelor's and master's degrees)

Ways to Involve Faculty in IL

docs.google.com/document/d/1LTTiA8HwcDjVJ-M35QYSZAznpf3i98Lqp6W39elTQHw/pub

Summary of ideas: It is an iterative, long-time process to help faculty be aware of the opportunities. Demonstrate to the faculty that student work will improve if students participate in information literacy activities. We can do that demonstration in class. -Bill Badke 
- Help faculty to realize this is about their courses, students, and their students' learning. It's not about librarians pushing into their classes, but their vested interests we're trying to tap into.

- Get a required IL course into the curriculum-faculty see the difference in students who take the course. Some may require that course as a prerequisite or corequisite of their courses.

- Never take for granted that faculty understand what IL is or how it affects their students, etc. It takes constant effort to keep faculty engaged and new faculty learning about it. Have your academic dean and faculty work together on this.

- Stay in contact with faculty. Initiate by talking with the professors directly in person. They need the education as well on how to use resources and how to construct instructions without dated methods, requirements, or prohibitions such as no online resources allowed. If the faculty use it too, the students will learn alongside. Remember that not everyone will cooperate.

- Try to show faculty the difference in quality of student papers in the outcome. We asked faculty in a faculty meeting whether they liked the research papers their students were turning in. When they said no, I suggested having their students meet with me one-on-one each semester. The result has been four or five faculty members now requiring this each semester in all of their classes involving research papers.

- What if online only? How to initiate with faculty? Make a video in Canvas or through Screencasting. Put it where they can incorporate it into the course. If online only, provide good research support. Philllps Seminary is small and is online now. We mail books, scan and send articles, whatever is needed. We do the legwork since students can’t be here in person. 